\title{
Censorship \& Literature in the Arab World
}

\author{
Dr Tarek Musleh * \\ professor of English literature at Jadara University in Jordan \\ *Corresponding Authors: Dr Tarek Musleh, professor of English literature at Jadara University in \\ Jordan
}

\begin{abstract}
The nature of literature necessitates the freedom of expression without any censorship whatsoever. If writers feel the pressure of the outside world which imposes on them certain restrictions they will be crippled and their literature may be marred whether partly, largely or wholly depending on the power of the censor.

The main reason of censorship in the Arab world is related to the structure and development of Arab character and recent history. The Arabs are now torn between allegiance to heritage and between confronting reality by adapting to the demands of contemporary life. On the one hand, the fundamentalists want to restore the old style of life by adopting a literal approach to religious texts and they feel threatened by the idea of change; on the other hand, the liberals accept Western culture as exemplary and they attempt to reconcile the past with the present. Similarly, Arabic literature is dominated by 'preaching', but increasingly tries to assert itself against all sorts of odds by confronting the challenges of modern life. In order to achieve an international status, Arabic literature has to confront human nature freely without any censorship.
\end{abstract}

Keywords: Censorship, Arabic Culture, Islam, Tradition, Fundamentalism, Modernism, Arabic Literature, Liberalism

Throughout history literature has been subjected to various forms of censorship and consequently many writers have been harassed, blackmailed, imprisoned, tortured or even killed. With some reservation, the West has recently done away with censorship and writers may relatively write freely about any subject under the sun, unlike the East where censorship still prevails owing largely to the power of fundamentalism which dominates the Arab world.

The main reason for censorship is usually fear of the other and a blind belief that those self-appointed guardians of culture, to use Foucault's expression, are on the right track. The usual excuse is that they have to protect the moral structure of society and often they use religion as a pretext to justify whatever step they take against 'corrupt' writers. The so-called guardians do not realise that their kind of oppression is a declaration of belonging to a one-sided and self-complacent culture and a form of intellectual poverty and even bankruptcy, especially when they abuse power to impose their judgement on others.

There is no doubt that censorship has somehow determined the kind of literature that is allowed for publication which is usually committed to national, social or religious causes that may not correspond with the individual ideology of writers. Most liberal minded writers reject any form of manipulation that can influence their writing and they try to use literature to 'entertain' the reader and promote their ideas through dramatising whatever aspect of life they are convinced of. They feel it is their duty to dramatise every aspect of human life freely without any distortion or compliance with oppressive and artificial laws. Moreover, many writers insist that literature has nothing to do with morality which is often relative, and has something to do with adapting to traditional and dogmatic principles. Ideally, writers should have the absolute freedom to dramatize whatever they feel inclined to write about, providing their literature is not openly didactic to promote certain causes. If their ideas are positive or negative, this is their own concern, despite the fact that the 'negative' is generally a better material for literature. Writers should not represent statues but people of flesh and blood, should explore human nature as it is, the world of imagination, and even the so-called abnormal side of humans. The ideal principle for literature is: deviation is the norm. Once Al-Asma'i said, "the best poetry is the most deceptive." (Al-Bagdadi, 564) Also when the poet Hassan Ibn Thabet was asked about the reason of the decline of his poetry, his blatant answer was, "it is Islam", (Al-Asfahani, 253) that is, persistent 
commitment to a particular ideology may drive writers away from their art or preclude exploring all aspects of human nature.

Many fundamentalists who are devoted to censorship claim that our culture necessitates illustrating characters which reflect our Arab ideals assuming that the West is totally different from the East ignoring that People are human wherever they are. The fundamentalists in particular, who boast about some fixed national ideals and principles, illustrate the West as evil, corrupt and materialistic, and the East as virtuous, spiritual and Romantic. In reality, corruption in the East is pervasive, in addition to the artificial restrictions which stifle individuality. People have most of the time to have a double face. The actual difference between the East and the West is in theorizing and this usually creates an unhealthy gap between theory and practice. Many people in the West, especially the intelligentsia, evaluate everything on the basis of how practical it is, without any reference to religion or tradition. Individuals don't usually feel guilty if they are personally convinced of whatever they are doing. Exploring all sides of the recesses of human nature should be the ideal of all writers wherever they are regardless of any consequences.

The fundamentalists do not realize that the pressure of modern life in addition to present circumstances necessitate a new approach of reinterpreting religious texts in a flexible way. Interest, inheritance, the feminist question and the freedom of expression are generally some of the pressing issues that have to be tackled anew. Rationalization, based on experiment, should be adopted primarily as necessary requirement of modern practical life; this trend is also encouraged by the nature of language and the ambiguity of many religious texts.

More than a thousand years ago Al-Mutazilah courageously affirmed, "If there is a contradiction between the text and reason we shall adopt reason and interpret the text metaphorically." (Al-Bagdadi, 406) On the other hand, educated people in the West have developed a form of Christian deism whereby they concentrated on the individual behavior in a healthy society, rather than on rituals or miracles.

The ultimate question is whether there is a mechanism in Islam to enable scholars to respond positively to modern contexts of life and the soul of texts rather than to their literal dimension. Is it possible to reconcile the present demands of life with the literal approach of the fundamentalists? Furthermore, Should Arabs reject modernization on the basis of its foreignness and stick to their own cultural values, or should they at least try to find a compromise, especially many educated people are not quite convinced of the validity of their own tradition. A strict adherence to heritage is something which the Arabs have had to deal with since the emergence of Islam. Perhaps the only significant exception is that of the 'rationalist' movement of al-Mu'utazilite which challenged the religious orthodoxy and went so far as adopting a metaphorical interpretation of many Koranic verses which literally, from their point of view, contradicted with reason; they also raised doubts about some of the issues which are now beginning to emerge again. Had al-Mu'utazilite been allowed to continue as a movement, it would probably have adopted a deistic approach to religion where there is less attention either for rituals or miracles and where the practical welfare of humans is given top priority, exactly as the west has done with Christianity. In recent times, al-Afagani, Muhammed Abdo, Kasem Amin, Shaltout, Ahmad Amin, Taha Hussein and many others started a movement of liberation, but again religious orthodoxy prevailed. At the moment, the Arab satellite channels are monitoring religious interpretations and trying by hook or by crook to preach traditional ideals as the only viable approach to Islam. Their attitude to individual freedom of expression in general is quite negative and uncompromising; their outlook is one sided, presenting reality as either right or wrong concerning every aspect of life, including trivial details about one's own personal matters. They sometimes rely on a decontextualized literal interpretation of religious texts and deny any possibility of maneuver or of adopting a metaphorical interpretation of some Koranic verses.

The basic issue which the fundamentalists ignore is that religion is there to help humans survive comfortably; and it should have a mechanism to change if circumstances demand, particularly by using analogy. Jesus once said to those who were protesting against not observing the Sabbath, "the Sabbath was made for humans, not humans for the Sabbath." (Mark 2:27) In other words, humans are the center, and everything else should be devoted to ensure their happiness on earth. Western culture has actually developed a philosophy of liberal humanism where individuals are by and large free to do whatever they want, providing of course no one else is harmed. In Arab cultural ideology, society is the center and individuals are expected to sacrifice themselves to serve their family, country, religion, 
etc. Perhaps some form of compromise is possible between extreme individualism and those external forces which limit and oppress the individual. In terms of any religious practice, the Moslem has to be logically convinced of whatever he/she is performing rather than the negative assertion, which is sometimes out of context, that this is merely mentioned in the Koran, or supported by Hadith. There is generally intellectual poverty on the part of orthodoxy which is driving many educated people to the West rather than allowing them to re-evaluate their tradition in the light of new circumstances and then establish their own personal judgments. Some of those pro-Western scholars are further encouraged by modern theories of linguistics and literary criticism, especially Deconstruction (Bertens, 117-124), that have thrown doubts on the unity of the text which is often seen as a rich and lively entity between writer and reader. Accordingly, the possibility of more than one interpretation is always dormant within every text and each generation might find something new and totally different from the original interpretation, especially, as Nietzsche has remarked, language by nature is metaphorical (Ellman 847).

There is an uneven battle at the moment between the fundamentalists who stick to the old interpretation of the Koran and Hadith and some modernists, such as Nasr Abu Zaid, who are trying to raise doubts about the "fixity" and "stability" of religious texts (Abu Zeid 55-61). Probably new voices will emerge to enrich research concerning how to approach the religious text in particular. Despite unfavorable circumstances, it is hoped that some approach which is flexible, pragmatic and tolerant might be adopted, although the conflict between the old and the new, in the words of Taha Hussein (Wednesday talks 3-9) will never be over.

This ideological background of censorship in the Arab world has led to imposing various forms of measures against writers.

There is no doubt that legal and judicial accountability is not the only means employed to achieve this. There is also the manner of political accountability through interrogations, parliamentary questions, propaganda campaigns, and banning. Administrative and governmental procedures often prevent writers from printing literary works, confiscating them, withdrawing them from the markets, imposing restrictions on them, and forcing the writers to explicitly or implicitly write off some of their content. Then there are various methods of religious repression against writers and thinkers like forbidding reading their books or viewing their literary works, selling them, buying them, marketing them; this may also lead to eventually banning them legally. This is also followed by the method of suppression and physical abuse against writers, by threatening them, torturing them, and finally adopting the method of social exclusion that is not limited to the writer, but extends to his children, his wife and his family. The repression is numerous and the images are repeated. A striking example is the case of the pursuit of Nasr Hamed Abu Zeid, forcing his wife to divorce him, displacing him and not allowing him to go back to his country Egypt simply for publishing his book Thinking at the Time of Blasphemy Accusation. Another example of banning and defamation is that of Nawal alSaadawi 's novel, The Fall of The Imam for containing 'blasphemous' passages from the fundamentalists' point of view.

A third example revolves around the novel The Children of Our Neighbors by Naguib Mahfouz, who was accused of insulting the prophets and 'stabbing' the divine self. Two reports of the Islamic Research Academy banned the book. In fact, the first edition of Dar al-Adab was published in Beirut in 1962 and was not printed in Egypt until 2006, when it was published by Dar al-Shorouk. Mahfouz agreed with the personal representative of Egyptian President Gamal Abdel Nasser, not to publish the book without the approval of Al-Azhar, the highest religious authority in Egypt. The novel was written by Mahfouz when he saw the deviation of the 1952 revolution from its slogans and principles. It came in symbolic criticism of Nasserite power. Despite its deep symbolism, some interpreters view it as seeking reconciliation between science and religion. The fundamentalist cleric Umar Abdurrahman passed death sentence on Najib Mahfouz. This led one of the mobs to follow Mahfouz when he left his house for his seminar, and stab him with a knife in his neck in 1994, which had a deep impact on his health and his ability to hold his pen to write again.

The dominance of fundamentalist censorship, whether directly or indirectly, has made Arabic literature move in a vicious circle. It primarily represents a culture where everything has to be supervised. Many Arab writers are committed to society, nationalism and/or religion; and they try in one way or another to reform the individual. Literature is there to change people and instruct them about how to conduct the best form of behavior. Narrators are usually intrusive, and they particularly 
appear in authorial mouthpieces that every now and then bombard the reader with religious and popular slogans such as "murder will out," or "God's mill is slow but sure", or "the wings of lying are short". Under such manipulation, there is not a real sense of suspense and the line of development could easily be predicted. In other words, there are no real shocks or surprises or complexity of situations, and there is usually a sense of finality presented either in marriage or death or reformation. Rarely do we have an open ending work that is complex enough to make us puzzled, and to speculate about what is going to happen next. Moreover, Arab writers are often openly didactic. Their enthusiasm to deliver a message makes their literature direct without usually being able to dramatize any theme convincingly. The characters appear at times as puppets and the resolution imposed from above rather than springing from within. There is little or no artistic distance between the writer and his material. Furthermore, the religious culture of the Arabs has made them glorify one form of Arabic, namely, formal, or classical Arabic, which most writers use in all situations, unlike Western fiction, which employs local dialects extensively. Regardless of any consideration, formal Arabic is not suited to be employed all the time in fiction especially when writers want to convey the actual wording of what goes inside their characters' mind, as in the stream of consciousness technique and more specifically in dialogue, simply because it is not used in actual life. If the character that is especially ordinary and uneducated is using formal Arabic, this will undoubtedly reduce its reality. Writers have to choose between formal Arabic, in which case their characters' reality is partially sacrificed, or between using a local dialect that appears realistic but may not be completely understood in certain parts of the Arab World.

Quite recently, there have been many Arab writers who are beginning to move towards modernism and respond favorably to globalization. Ghada al-Samman could be cited as an example of a feminist who is influenced by the West and is enthusiastic to preach equality among the sexes; but the clutches of didacticism are stifling her art. In Beirut 75 she could not help creating an authorial mouthpiece who has to be a poet in order to convey her own ideology about various aspects of life and existence. The novel is dangerously didactic, bordering on direct statements that are trying to present a case. Many melodramatic events spoil any attempt to prepare the reader psychologically to accept any situation. There are many scenes which disrupt our usual notion of probability; and certainly we have to be extremely tolerant to accept the sudden turn of events which are sometimes too shocking to be true.

It may not be quite fair that a bad example was chosen to represent the vast diversity of Arabic fiction, but even a great writer like Naguib Mahfouz falls into the trap of didacticism in different ways. In The Thief and the Dogs, for example, he attempts to represent the stream of consciousness technique of the main character, but he actually uses a language which is a middle way between formal Arabic and spoken Egyptian dialect, which is a kind of compromise between two extremes. This is an admirable attempt but hardly reflects the actual way a thief may use in actual life which is the main requirement of this technique. Moreover, he does not allow his thief to think as one, but in different ways intrudes into the narrative to criticize the contradictions within society, etc,:

"What a lot of graves there are laid out as far as the eye can see! Their headstones are like hands raised in surrender, though they are beyond being threatened by anything. It is a city of silence and truth, where success and failure, murderer and victim come together, where thieves and policeman lie side by side in peace for the first and last time." (The thief and the Dogs, 164)

This organized and sophisticated formulation of criticizing social life is hardly fit for a thief who is supposed to be confused, somehow shallow and uneducated. It is indeed part of Arab culture in all fields of life, including parents, teachers, educationalists, politicians and men of religion, to pose somehow as reformers or guardians of culture trying to change society the direct way. We do not assume that our victims of preaching may turn deaf ears if the style is not effective. Even at a university level, lecturing and even in some cases imposing rote learning by some teachers rather than encouraging free discussions is the main tool of teaching.

It seems that commitment in the Arab sense reduces the writer's attention, which should be focused on the literariness of literature, that is, on the artistic elements which make literature what it is. The damaging effect of censorship has brainwashed many writers and distorted their literature to the extent that their work has become more or less authorial mouthpieces. Western literature may not provide a healthy picture of individuality and may emphasize the fragmentary existence of a hopeless world "Waiting for Godot", but it is certainly more original and artistic than Arabic literature which is crippled by censorship and is still by and large on the survival side, dealing with social issues related 
to perfecting people's material life. Arab writers do not have to go as far as the sexual hallucinations of Molly Bloom in Ulysses, or the blatant rejection of all conventions by Mersault in The Outsider or the distorted human existence of much of the theater of the absurd, but they should at least abandon the idea of showing any sexuality outside marriage as unrealistic, and a form of deviation which has to be deplored.

\section{WOKS CITED}

Abu Zeid, Nasr, Thinking at the time of Blasphemy Accusation, Sina Publication, 2015.

Al-Bagdadi, Abdul-Kader, Islamic sects, Beirut: Dar al-Mashriq, 2018.

Al-Asfahani, Abu Faraj, Songs, Beirut: Dar al-Kutub al-Ilmieh, 2013.

Al-Samman, Ghada, Beirut 75, Samman Publication, 2016.

Bertens, Hans, 'Deconstruction', in Literary Theory: The Basics, Oxford University Press: 2002.

The Bible, Mark 2:27.

Ellmann, Richard (ed.), The Modern Tradition, New York: Oxford University Press, 1965.

Hussein, Taha, Wednesday Talks, Cairo: Dar al-Ma'arif, 1976.

Mahfouz, Naguib, The Thief and the Dogs, Cairo: Maktabet Misr, 1961.

\section{BIBLIOGRPHY}

[1] Allen, Roger (1995). "The Arabic Novel: an Historical and Critical Introduction" (2nd ed.). Syracuse University Press.

[2] Allen, Roger (2006). "The Arabic Literary Heritage: the Development of its Genres and Criticism". Cambridge University Press.

[3] Ashtiany, Julia; Johnstone, T. M.; Latham, J. D.; Serjeant, R. B.; Smith, G. Rex, ed. (1990). "Abbasid Belles-lettres". Cambridge University Press.

[4] Auchterlonie, Paul (1986). "Arabic Biographical Dictionaries: a Summary Guide and Bibliography". Middle East Libraries Committee.

[5] Beeston, A. F. L.; Johnstone T. M.; Serjeant, R. B.; Smith, G. R., ed. (1983). "Arabic Literature to the End of the Umayyad Period". Cambridge University Press.

[6] El-Enany, Rasheed (1993). "Naguib Mahfouz: the Pursuit of Meaning". Routledge.

[7] Glassé, Cyril (2001). "The New Encyclopedia of Islam". AltaMira Press.

[8] Hashmi, Alamgir, ed. (1986). "The Worlds of Muslim Imagination". Gulmohar.

[9] Hassan, Nawal Muhammad (1980). "Hayy Bin Yaqzan and Robinson Crusoe: a Study of an Early Arabic Impact on English Literature". Al-Rashid House for Publication.

[10] Jayyusi, Salma Khadra (1977). "Trends and Movements in Modern Arabic Poetry". Volume I.

[11] Jayyusi, Salma Khadra (1992). "The Romantic Poets". In Badawi, Mohammed Mustafa. "Modern Arabic Literature". Cambridge University Press.

[12] Jones, Alan (2003). "Foreword". In Rodwell, J. M. "The Koran". Phoenix.

[13] Logan, Peter Melville, ed. (2011). "The Encyclopedia of the Novel". Volume I. Wiley-Blackwell.

\section{AUTHORS' BIOGRAPHY}

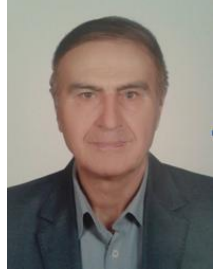

Dr Tarek Musleh is a graduate of Warwick University in England. He is currently a professor of English literature at Jadara University in Jordan. He has published a number of papers mostly on fiction and a book titled: English Fiction: From Defoe to Golding. His main interest is fiction, literary theory, comparative literature \& cultural studies.

Citation: Dr Tarek Musleh, "Censorship \& Literature in the Arab World" "International Journal on Studies in English Language and Literature (IJSELL), vol 8, no. 6, 2020, pp. 21-25. doi: http://dx.doi.org/ 10.20431/2347-3134.0806003.

Copyright: () 2020 Authors. This is an open-access article distributed under the terms of the Creative Commons Attribution License, which permits unrestricted use, distribution, and reproduction in any medium, provided the original author and source are credited. 